\title{
Identifying the English Reformation
}

\author{
Susan Wabuda \\ Professor of History, Department of History, Fordham University, 441, East \\ Fordham Road, Bronx, New York 10458-5159, USA. Email: wabuda@fordham.edu
}

Peter Marshall, Heretics and Believers: a History of the English Reformation, Yale University Press, 2017, pp. xx +652, £20.40, ISBN: 978-0300170627

The story of the Reformation in England is full of paradoxes and incompatibilities that have never been easy to fit into a coherent narrative. A. G. Dickens established the English Reformation as its own historical category in a best-selling text book that he first published in 1964. The English Reformation was remarkable for the new emphasis that Dickens placed on acts of state that imposed religious change from above, led by Henry VIII, Thomas Cromwell and the Protector Somerset, Edward Seymour. He argued that their measures were met with a ground-swelling of acceptance from the people below. Dickens highlighted the important roles that popular opinion also played in the making of the Reformation in England, seen through local events and especially through the bequests of their souls that ordinary men and women made in their wills. A pervasive anticlericalism, which stemmed from the rise of Lollardy in the fourteenth century, was one of Dickens's major themes. Even the Pilgrimage of Grace of 1536 in the north of England, the most dangerous act of resistance that Henry faced, had among its leaders, a 'violent Protestant' in the eccentric Sir Francis Bigod (124). Although The English Reformation was enormously influential, it was also deliberately 'Whiggish', for Dickens framed the ultimate success of Protestantism in England as a triumphal progression that was essentially complete soon after Elizabeth reached the throne in 1558. Some of the Reformation's greatest and most complex questions, which arose later in the century, were never fully addressed. Among the 'residual problems' that he merely glanced at were English Catholicism ('re-created', he argued, by the 'adventurous labours' of the Jesuits, 311), and Puritanism ('a brief anatomy', 313).

His contention that Protestantism had become ineradicable at the start of Elizabeth's reign had already been defeated by 1989, when he made the mistake of repeating his arguments in the second, lightly revised edition of The English Reformation. By then, his view of the Reformation as an early sixteenth-century phenomenon had been 
thoroughly put to rest by younger colleagues, revisionist scholars like John Bossy in The English Catholic Community 1570-1850 (1976), and Patrick Collinson in The Elizabethan Puritan Movement (1967). In the late 1950s Collinson was one of the members of the Tudor Seminar at the University of London's Institute of Historical Research to whom Dickens dedicated the first edition of The English Reformation. Like Bossy, Collinson had been inspired by Dickens's methods, but disavowed his automatic assumptions. There was no dedication in Dickens's second edition.

Every generation asks its own questions about the past, and that the Reformation in England was of a longue durée, cannot now be doubted. Among the revisionists, no book has had more influence in the last quarter century than Eamon Duffy's evocative The Stripping of the Altars (1992), which characterized the Reformation in England as a series of startling disruptions in the continuity of traditional religion and medieval devotion. In successive reigns, the Tudor state imposed itself upon believers in the pew. Most of the action was again set in the first half of the sixteenth century. Duffy's chapter on Elizabeth's reign was brief, and it pitted patterns of suppression against 'varying degrees of traditionalist persistence' (582).

The Stripping of the Altars appeared a year before Christopher Haigh's English Reformations: Religion, Politics and Society under the Tudors (1993), which also stressed the role that the state played in instituting religious change. Earlier, J. J. Scarisbrick's The Reformation and the English People (1984) observed that most English men and women did not want the Reformation when it arrived. Together with Duffy's Stripping of the Altars, Haigh and Scarisbrick have played a dominate role in defining recent perceptions about the Reformation. Where Dickens saw ready acceptance of religious changes, they noted popular reluctance.

At the same time, Diarmaid MacCulloch's award-winning study Thomas Cranmer: a Life appeared in 1996, followed rapidly by his The Boy King: Edward VI and the Protestant Reformation (1999): a close examination of religious change during the reign of Henry's son, who died at the age of fifteen in 1553. MacCulloch's most recent books have included The Reformation: A History (2003), a wide-ranging survey from a European perspective; and All Things Made New: Writings on the Reformation (2012), a collection of essays on a rich variety of topics.

The conundrums from all sides of the revisionists' arguments have been difficult to reconcile in a truly satisfying account of the Reformation in England, one that considers the many contradictions and uncertainties that can be observed well beyond the mid-century mark. In their 2002 introduction to a collection of essays in The Beginning of English Protestantism, Peter Marshall and Alec Ryrie 
identified the extent to which Dickens's story of the English Reformation no longer made sense. They also noted the ways that the revisionists left gaps in the historical narrative.

Now Marshall has presented a fresh, compelling, and lucid account in Heretics and Believers: A History of the English Reformation. His book is remarkable for its reasoned impartiality. He presents his story without extensive reference to the academic debates and controversies that have dominated the field for more than a half century. Marshall carries the narrative from the beginning of the sixteenth century to Elizabeth's last decade in the 1590s. He argues that the assumption that the Reformation in England was imposed by successive governments upon an unwilling people can no longer be accepted as helpful in understanding what actually occurred, because the Reformation in England was achieved at the expense of eroding the power of the government as it attempted to force the people to comply. Instead of simply obeying, ordinary men and women were empowered to think things through for themselves. They chose to accept or resist. A constantly changing diet of religious change did not bewilder them, as Duffy or Haigh once thought. Instead, the English people thought seriously about the questions that the Reformation raised, and they were prepared to discuss them almost everywhere: in marketplaces and in taverns, and at church and at the dinner table. Nor was resistance to the government's policies as limited as Dickens implied. Outward conformity frequently concealed privately-held opinions. During the Reformation, the mystique of the monarchy was 'fatally undermined'. In every reign the Tudor state may have insisted upon obedience and uniformity in belief and practice, but instead the meaning of 'religion' itself fundamentally changed, because the ways and habits of 'doing' religion were transformed. Pluralism and division became instead the defining characteristics of English religious life. Henry VIII 'opened a Pandora's box of plurality' (xiii) when he permitted evangelical reformers to make their case from pulpits and in print. The 'imposition of the Reformation was the pyrrhic victory of the English state' (xii) because many people realized that they could not share the version of Christian truth that was promoted by the highest authorities in the land.

Marshall explores the dynamic nature of religion at the end of the middle ages, and he argues that the Christian Church was constantly changing. New ways were continually found to make things holy. Heretics and Believers shows that the durable certainties that Dickens and Duffy sought to establish have been outmoded. From the beginning, historians have underestimated how alarmingly unregulated the late medieval Church was, and also how internally riven it was by dangerous competitions. At the beginning of the sixteenth century, the Church was surprisingly fragile. Its standards for 
its own probity were not only high: they were sometimes unattainable. Rather than the anticlericalism that Dickens emphasized, popular criticism was motivated by 'disappointed expectation' (64). At first, improvements and reforms were expected to come from inside the Church itself, as illustrated by John Colet's famous Convocation sermon of 1512. But Marshall notes that insufficient attention has been paid recently to the tensions and rivalries that threatened the late medieval Church's cohesion. Contentious rivalries between members of the religious orders, and Thomas Wolsey's dominate role as cardinal legate and Henry's chief minister, created their own sets of problems that could not be easily solved. The ideals that Erasmus and other humanists fostered served to encourage both a yearning for God as well as a perspective that was critical of traditional piety. The desire for some kind reformation as improvements in the Church was widely recognized, but society was unable to agree on ways to implement them, which helps to explain why England could not rise with a united front to address the unanticipated challenges that Martin Luther posed. However, he points out, the real wellsprings of the Reformation in England can be discovered not in the weaknesses in the life of the Church, but rather, in its many successes: in encouraging an intense concern with salvation in people of all stations of life, and in building in them the sense of a personal relationship with God. An intense focus on Jesus and his holy name was a marked feature of popular devotion (149).

With ease and sensitivity, Marshall considers a vast array of subjects in his book. His account is clear and accessible for a wide range of readers. He addresses such difficult subjects as the extent of the debt that the evangelical reformers owed to the Lollards; or the complex implications of the royal supremacy over the English Church. He uses perceptive, pithy summaries to make his points. His surprising observations impress: 'The early Reformation in England had a sympathetic Lollard godmother, but its parents were orthodox and Catholic' (140). Henry's theology was 'a moving target, a work in progress, a nest of contradictions' (295). 'New Christianities' (the subject of the third and most central portion of the book) were created. Royal policy spilled blood. Sir Thomas More and the Carthusian monks were executed. Sustained persecution turned some Catholics into Roman Catholics. In one of his most profound observations, Marshall remarks: "Henry VIII was the creator of English Roman Catholicism just as much as he was the progenitor of "Anglicanism".' (225).

At the old king's death at the beginning of 1547, 'rival schedules of hope and ambition' (302) were unleashed between 'evangelicals, conservatives, pragmatists and enigmas' (304). The evangelicals achieved a cautious, circumspect victory that allowed Somerset and Cranmer to move Edward's Church further than his father ever 
allowed. The achievements of Edward's reign included the Book of Homilies, and English liturgy in the Book of Common Prayer. In 1549 the first Prayer Book, and a comprehensive attack against religious images in the parishes led to the second great rebellion that the Tudor dynasty faced, this time in the western counties and East Anglia. The government was nearly unseated. To regain control, an 'ocean of blood' was spilled (342). Somerset was sacrificed. Meanwhile, Cranmer persisted in the building of a Protestant Church, drawing now from Strasbourg, Geneva, and Zürich as well as Wittenberg. A second, revised Prayer Book was released in late 1552. Yet as the young king's health failed, Cranmer was only too aware that "“Antichrist is not yet slain." (353). The attempt in 1553 to place Lady Jane Grey on the throne instead of Edward's Catholic sister Mary failed within two weeks of the king's death.

Parochial restoration during Mary's reign was challenging, because altars and other sacred objects had been 'profoundly, irremediably politicized': to replace them was 'a statement of faith in an alternative future, not an invocation of some vanished past.' (381). There could be no restoration because there was no return to things as they had been before the 1530s. Not only had Catholic practices been withdrawn under Edward, but the arguments that engaged the English people had also changed. So too had the Catholic Church undertaken a thorough self-examination at the Council of Trent. When England rejoined Rome, the old monasteries, convents and friaries could not be revived as they had been before the dissolution, because too much of their landed properties had been granted to the laity. Instead, the seven religious houses that were opened in Mary's reign (with plans for more) were technically new foundations (402). Cranmer and other bishops, like dozens of ordinary people, went to the stake. More fortunate evangelicals fled to exile in Strasbourg and Geneva. Other Protestants wore out the time in uneasy accommodation with Mary's government. They were the quiet 'Nicodemites' who did not proclaim their faith against whom John Calvin warned.

In summarizing the results of Mary's reign, Marshall argues that both traditionalists and reformers 'were at once transformed' and even strengthened. A 'more articulate, combative, and committed Roman Catholicism' emerged. A 'more determined and doctrinaire Protestant movement' evolved, one released from its dependence on the royal supremacy (415). Yet, Mary's full potential was wasted by her early death as surely as her brother's had been. Each reign left behind many 'unattainable prizes', which in the fourth section of his book, Marshall argues was also one of Elizabeth's real legacies.

At Elizabeth's accession, the Nicodemites gained control. The faith of the queen and her chief minister had been forged under Henry, matured by Cranmer under Edward, and prudently safeguarded under 
Mary. There were no Henrician Catholics, and no "Genevans"” when the Elizabethan Church was given its shape (422). Many of the returning exiles were disappointed, but dissent was not encouraged. Had he been allowed to live, Cranmer might have continued to revise the Prayer Book. Had Elizabeth wished, further steps could have been taken 'to bring Church and society to a restored condition of apostolic purity by stages and degrees' (434). But that did not happen. The queen did not share the exiles' sense that "Reformation" was a journey; a continual striving after elusive perfection, in the world and in oneself'. Rather, from the beginning of her reign, the queen believed that the process of reformation 'was over.' (434) Marshall describes her Protestantism as 'of a distinctly willful and wayward kind' (446). In her precarious youth she had learned the value of inwardness, and when to take a stand on principal. Elizabeth 'reigned in a profoundly anti-Nicodemite age, and her attempts to contain religious tensions had an inescapable tendency to inflame them.' (466) She faced persistent demands from her bishops and the former exiles, yet she withstood them when she displayed a cross or crucifix in her private chapel or turned a deaf ear to their criticism of vestments. When Archbishop Edmund Grindal had the temerity to admonish that she was merely mortal, she all but deprived him. Nor could Catholics gain advantages in light of the threats posed by Mary Queen of Scots and a hostile Pope Pius V.

For Marshall, real Protestant roots were not laid down in the parishes until the third decade of Elizabeth's reign, and even then 'not in the exact forms the most zealous godly clergy would have liked' (541). Over time, Protestant culture began to become regular and local. Parish churches now possessed Bibles, the homilies, the Paraphrases of Erasmus, and John Foxe's Actes and Monuments. Parish account books attest to the purchase of wine for Communion services at Christmas, Easter, and Whitsun. Wills show that the Bible was also a household possession. More than one hundred books of religious instructions and catechisms in many editions poured from English presses by 1586. The men and women who had been born under the papacy eventually died of old age. Thus with the passage of time, changes had been 'achieved by a kind of cultural inhalation'. England had made a 'gradual transformation into a properly Protestant nation.' (543).

Heretics and Believers rewards its readers with a comprehensive analysis of the Reformation's effect upon regular lives. Notable crises of conscience are explored across the emerging doctrinal spectrums. Many of the stories Marshall tells are deeply moving. Among those who also died in the struggles included Elizabeth Barton, the Nun of Kent; Robert Barnes; Bishop John Fisher; and William Tyndale, whose 'faith was energized by questioning and contradiction' (372). 
Through a prolonged and blood-soaked transformation, England eventually became Protestant. As a creative as well as a destabilizing force, the Reformation has had no discernable end. Marshall warns that some historians may think that in ending his story around the year 1590 'my Reformation (if not my book itself) is a little on the short side' (xviii). He has managed to fold in his six hundred and fifty pages the most clear and comprehensive history of the English Reformation yet written. Heretics and Believers is a triumph. 